\title{
Inhibition of Drug Metabolizing Enzymes (Cytochrome P450) in Vitro as Well as in Vivo by Phyllanthus amarus Schuм \& ThоNN
}

\author{
Kuzhuvelil Bhaskarannair HARI KUMAR and Ramadasan KutTAN* \\ Amala Cancer Research Centre; Amala Nagar, Thrissur, 680555, India. \\ Received November 21, 2005; accepted April 1, 2006
}

\begin{abstract}
An alcoholic extract of Phyllanthus amarus (P. amarus) was found to inhibit cytochrome P450 (P450) enzymes both in vivo as well as in vitro. This was studied using specific resorufin derivatives, as substrate for isoenzymes in the $\mathbf{P 4 5 0}$ super family. Concentration needed for $\mathbf{5 0 \%}$ inhibition of 7-ethoxyresorufin- $O$-deethylase (EROD), CYP1A1 was $4.6 \mu \mathrm{g} / \mathrm{ml}$ while concentration needed for 7-methoxyresorufin- $O$-demethylase (MROD) CYP1A2 was $7.725 \mu \mathrm{g} / \mathrm{ml}$ and 7-pentoxyresorufin- $O$-depentylase (PROD), CYP2B1/2 was found to be $4.18 \mu \mathrm{g} / \mathrm{ml}$ indicating that the extract inhibited the $\mathbf{P 4 5 0}$ enzymes at very low concentration. Extract also inhibited the activity of aniline hydroxylase (an indicator of CYP $2 \mathrm{E} 1$ activity, $\mathrm{IC}_{50}-50 \mu \mathrm{g} / \mathrm{ml}$ ) and aminopyrine demethylase (an indicator of CYP 1A, 2A 2B, 2D and $3 \mathrm{~A}$ activity, $\left.\mathrm{IC}_{50}>1000 \mu \mathrm{g} / \mathrm{ml}\right)$. Oral administration of the extract was also found to reduce the elevated P450 enzyme activities produced by phenobarbitone by $50 \%$ at $250 \mathrm{mg} / \mathrm{kg} \mathrm{body}$ weight. The implication of these results on the inhibition of carcinogenesis produced by the extract is discussed.
\end{abstract}

Key words cytochrome P450; phenobarbitone; xenobiotic; Phyllanthus amarus

Cytochrome P450 (P450) enzymes are microsomal heme containing monoxygenases located in the endoplasmic reticulum. P450 is a major superfamily of enzymes involved in the drug metabolism. About 150 isoforms of P450 has been identified depending upon reaction, which it catalyzes. The significance of these enzymes lies in their ability to detoxify a wide range of xenobiotics, exogenous and endogenous compounds, dietary constituents and environmental toxins through a two-electron reduction of molecular oxygen to form reactive oxygen species and water. Action of P450 can generate potentially carcinogenic or toxic compounds during the metabolism of xenobiotics. ${ }^{1,2)}$ For example benzo(a) pyrene and other polyaromatic hydrocarbons are metabolized in the body by P450 enzymes. They are converted to their diol epoxide which can then produce adducts with DNA. These DNA adducts produce mutation and subsequent transformation of the normal cell to cancer cells. P450 system can be influenced by a number of exogenous and endogenous factors and its induction and inhibition is of the utmost interest in carcinogenesis ${ }^{3)}$ as well as the bioavailability and activity of the drug.

CYP 1A1, 1A2, and 2B family activate certain promutagens such as benzopyrene (B (a) P) and other environmental pollutants metabolically to their ultimate carcinogenic form. The regulation of these enzymes may be one of the key mechanisms in cancer prevention and there fore potent inhibitors of these enzymes are good candidates as chemopreventive substances against cancer.

Phyllanthus amarus Schum \& THONN (Family-Euphorbiaceae) has been reported to have excellent anti-carcinogenic activity. It inhibited $N$-nitrosodiethyl amine (NDEA) induced hepatocellular carcinoma (HCC) in Wistar rats and also increased the life span of NDEA induced HCC harboring animals. ${ }^{4)}$ Administration of $P$. amarus also inhibited the sarcoma development induced by 20 -methyl cholanthrene. ${ }^{5)} \mathrm{N}$ Methyl- $N$-nitrosoguanosine (MNNG) induced stomach papilloma and Dimethyl benz(a) anthracene (DMBA) induced two-stage skin carcinogenesis were inhibited by $P$. amarus administration. ${ }^{6}$ P. amarus also demonstrated to have an- timutagenic activity to a variety of direct acting as well as carcinogens needing microsomal activation. ${ }^{7)}$ P. amarus extract inhibited the cell cycle regulatory enzymes cdc 25 phosphatase. ${ }^{5)}$ We have also reported its chemoprotective activity against cyclophosphamide induced toxicity. ${ }^{8)}$ In the present study we have evaluated inhibition of phenobarbitone induced P450 enzymes present in the microsomal fraction by an extract of $P$. amarus.

\section{MATERIALS AND METHODS}

Materials Young male Wistar rats $(180$ - 200 g) were purchased from Small Animal Breeding Station, Kerala Agricultural University, Thrissur. They were housed in wellventilated polypropylene cages under controlled temperature, and humidity and were provided with normal mouse chow (Sai Durga Feeds and Foods, Bangalore) and water ad libitum. The animal experiments were conducted after getting prior permission from Institutional Animal Ethics Committee (IAEC) and as per the instructions prescribed by the Committee for the Purpose of Control and Supervision of Experiments on Animals (CPCSEA), Ministry of Environment and Forest, Government of India.

Resorufin, 7-ethoxy resorufin (ER), 7-pentoxyresorufin (PR), 7-methoxy resorufin (MR) were obtained from SigmaAldrich Inc., U.S.A. Phenobarbitone (Gardenal $^{\circledR}$ 60, Batch No. B03007) was purchased from Nicholas-Piramel India Ltd, Gujarat. Nicotinamide adenine dinucleotide phosphate reduced (NADPH) was obtained from Sisco Research Laboratories Pvt. Ltd., Mumbai, India. All other chemicals used in the present study were of analytical reagent grade.

Analytical Procedures. Preparation of P. amarus Extract Aerial parts (stem and leaves) of authenticated $P$. amarus were collected from Thrissur district of Kerala State and were dried at $45^{\circ} \mathrm{C}$. A voucher specimen of the plant was identified and kept in the herbarium (voucher no. Eup-9) of Amala Ayurvedic Hospital and Research Centre. Dried parts of $P$. amarus were powdered and extracted $(100 \mathrm{~g})$ twice with five times $(500 \mathrm{ml})$ volume of $75 \%$ methanol by 
stirring overnight at the room temperature. The solution was then centrifuged at $2500 \mathrm{rpm}$ to separate the supernatant and the supernatant was evaporated to dryness at $50^{\circ} \mathrm{C}$ using a rotary evaporator under reduced pressure. The yield of the preparation was $7.9 \%$. Portion of the extract was reconstituted in distilled water at desired concentration just before the experiment. For all the animal studies P. amarus was administered through oral gavage.

Induction of Cytochrome P450 Enzymes The rats were administered with phenobarbitone continuously for $4 \mathrm{~d}$ $(60 \mathrm{mg} / \mathrm{kg} \mathrm{b}$. wt., intraperitonially, once daily). All the animals were sacrificed $24 \mathrm{~h}$ after the last dose of phenobarbitone. The livers of all the animals were excised quickly and washed thoroughly in ice-cold saline and kept at $-70^{\circ} \mathrm{C}$. $25 \%$ of homogenate was prepared in cold phosphate buffer $(\mathrm{pH} 7.4,0.1 \mathrm{~m})$ Homogenate was initially centrifuged at $14000 \mathrm{~g}$ for $20 \mathrm{~min}$ in a cold centrifuge (Remi) and supernatant was separated. The supernatant was then further centrifuged at $105000 \boldsymbol{g}$ for $1 \mathrm{~h}$ in an ultracentrifuge (Sorvall ultracentrifuge) and microsomes obtained were washed and resuspended in cold phosphate buffer $(\mathrm{pH} 7.4,0.1 \mathrm{M})$ and used for the analysis of various P450 enzymes.

In Vitro Studies To study the effect of $P$. amarus on P450 isoenzymes in vitro, various concentrations of $P$. amarus $(0-10 \mu \mathrm{g} / \mathrm{ml})$ were incubated with microsomal fraction. The effect of $P$. amarus on the dealkylation of metoxy resorufin by 7-methoxyresorufin- $O$-demethylase (MROD) CYP1A2, pentoxy resorufin by 7-pentoxyresorufin- $O$-depentylase (PROD), CYP2B1/2 and ethoxy resorufin by $7-$ ethoxyresorufin- $O$-deethylase (EROD), CYP1A1 were studied. ${ }^{9,10)}$ Briefly the assay mixture contained sodium phosphate buffer $(0.1 \mathrm{M}, \mathrm{pH} 7.4), 6.25 \mathrm{~mm} \mathrm{MgSO}_{4}, 60 \mu \mathrm{M}$ EDTA, $5 \mu \mathrm{M}$ ER or MR or PR, $100 \mu \mathrm{g}$ microsomal protein (from phenobarbitone alone treated animals), $100 \mu \mathrm{M}$ NADPH and various concentrations of the extract in a final volume of $1 \mathrm{ml}$. The reaction time was $5 \mathrm{~min}$ with a preincubation period of $5 \mathrm{~min}$ without the addition of NADPH at $37^{\circ} \mathrm{C}$. The reaction was stopped by the addition of $2 \mathrm{ml}$ of chilled methanol. The precipitated protein was centrifuged down and supernatant was used for the estimation of enzyme activity using a fluorescent spectrophotometer (Hitachi F-2500) at the excitation wavelength of $550 \mathrm{~nm}$ and the emission wavelength of $585 \mathrm{~nm}$. Blanks were set without any NADPH. The percentage inhibition was calculated by the following formula.

$$
C-T / C \times 100
$$

where $C$ is the optical density of control without $P$. amarus extract, $T$ is the optical density with $P$. amarus extract.

Inhibition of aniline hydroxylase activity (an indicator of CYP 2E1 activity) and Aminopyrene- $N$-demethylase activity (an indicator of CYP 1A, 2A 2B, 2D and 3A activity) were measured by the method of Mazel. ${ }^{11)}$

In Vivo Studies Twenty-eight rats were randomly divided into following four groups as follows

\begin{tabular}{cl} 
Group & \multicolumn{1}{c}{ Treatment } \\
I & Normal (without any treatment, $n=4)$ \\
II & Phenobarbitone alone $(n=8)$ \\
III & Phenobarbitone $+P$. amarus $250 \mathrm{mg} / \mathrm{kg} \mathrm{b}$. wt. $(n=8)$ \\
IV & Phenobarbitone $+P$. amarus $750 \mathrm{mg} / \mathrm{kg} \mathrm{b}$. wt. $(n=8)$
\end{tabular}

P. amarus was administered once daily for $15 \mathrm{~d}$. Administration of phenobarbitone was started on day 12 and continued for $4 \mathrm{~d}(60 \mathrm{mg} / \mathrm{kg}$ b. wt., intraperitonially, once daily). The liver microsomal fraction from $P$. amarus treated and untreated animals as prepared above were used to determine the activities of EROD, MROD and PROD. Calibration curves were constructed by determining the fluorescence of known amounts of the authentic resorufin. Concentration of protein in each sample is measured by the method of Lowry et al. ${ }^{12}$ ) Results were expressed as pmols of resorufin formed $/ \mathrm{min} / \mathrm{mg}$ protein for in vivo studies.

Statistical Analysis Data was expressed as mean \pm standard deviation (S.D.). Significance levels for comparison of differences were determined using ANOVA followed by Dunnett's test using Graphpad Instat software.

\section{RESULTS}

Administration of phenobarbitone at the doses given here significantly increased the P450 enzymes in the liver tissue. This could be expected as phenobarbitone administration has been shown to increase the transcription rate of several P450 forms in different species. Some of the P450 enzymes metabolize a number of xenobiotic agents and their induction increases the xenobiotic drug metabolism, which has a profound effect on the host.

In Vitro Inhibition of P450 Enzymes Using microsomal preparation we have tested the effect of $P$. amarus on the inhibition of P450 enzymes in vitro. Since the P450 enzymes are a super family of several (more than 150) isoforms with diverse substrate specificity it is not possible to analyze the effect on all the enzymes. However we had checked their effect on the isoforms of the genes CYP1A1, CYP1A2, CYP2B1/2, CYP2E1, CYP 1A, 2A, 2B, 2D and 3A. It has been known that CYP1A1 family metabolize the poly aromatic hydrocarbons, while CYP2E1 metabolizes the ethanol while CYP1A2 metabolizes aromatic amines. It was found that all the P450 enzymes are significantly inhibited by the $P$. amarus extract in a concentration dependent manner. Concentration needed for $50 \%$ inhibition of CYP1A1, CYP1A2, and CYP2B1/2 was almost similar $(<10 \mu \mathrm{g} / \mathrm{ml})$ while that of aniline hydroxylase $(62.38 \mu \mathrm{g} / \mathrm{ml})$ and aminopyrine- $N$ demethylase $(1000 \mu \mathrm{g} / \mathrm{ml})$ (Figs. 1, 2). Results are indicative

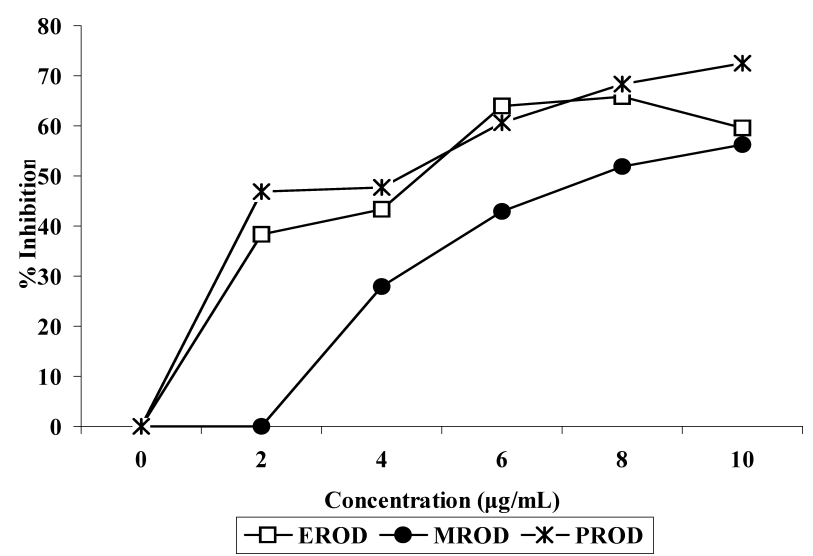

Fig. 1. Effect of P. amarus on Cytochrome P450 Enzymes in Vitro

The $\mathrm{IC}_{50}$ values of EROD, $4.65 \pm 0.05 \mu \mathrm{g} / \mathrm{ml}$, MROD, $7.79 \pm 0.06 \mu \mathrm{g} / \mathrm{ml}$ and PROD, $4.22 \pm 0.06 \mu \mathrm{g} / \mathrm{ml}$ 
Aniline hydroxylase

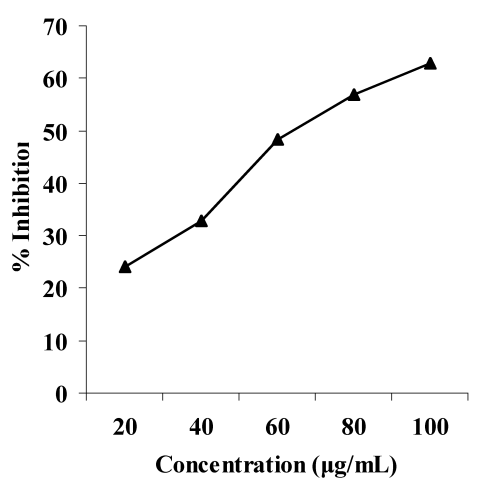

Aminopyrene-N- demethylase

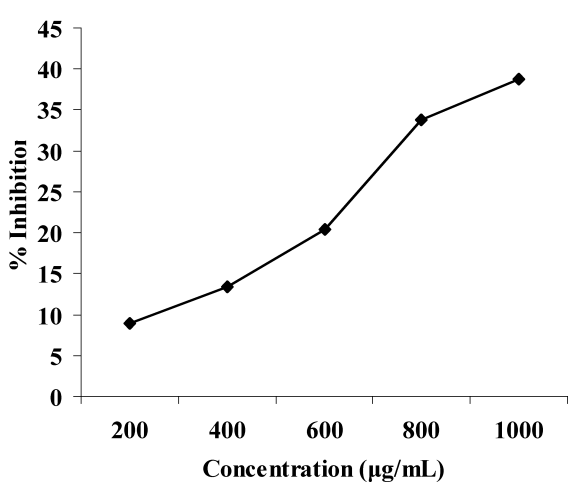

Fig. 2. Effect of P. amarus on Aniline Hydroxylase and Aminopyrene- $N$-demethylase Activity in Vitro

The $\mathrm{IC}_{50}$ aniline hydroxylase is $62.38 \pm 0.53 \mu \mathrm{g} / \mathrm{ml}$ and that aminopyrene- $N$-demethylase was above $1000 \mu \mathrm{g} / \mathrm{ml}$.

Table 1. Effect of Administration of P. amarus on Phenobarbitone Induced P450 Enzyme Activity

\begin{tabular}{|c|c|c|c|}
\hline Treatment & EROD & MROD & PROD \\
\hline Normal (without any treatment) & $36.81 \pm 14.80$ & $97.06 \pm 31.21$ & $12.90 \pm 4.51$ \\
\hline Phenobarbitone alone & $5323.60 \pm 1076.13 * * *$ & $891.50 \pm 337.61 * * *$ & $370.18 \pm 124.92 * * *$ \\
\hline $\begin{array}{l}\text { Phenobarbitone }+ \text { P. amarus } \\
250 \mathrm{mg} / \mathrm{kg} \mathrm{b} \text {. wt. }\end{array}$ & $1475.12 \pm 583.78^{*}$ & $318.87 \pm 69.88 *$ & $188.91 \pm 55.20 *$ \\
\hline $\begin{array}{l}\text { Phenobarbitone }+P \text {. amarus } \\
750 \mathrm{mg} / \mathrm{kg} \mathrm{b} \text {. wt. }\end{array}$ & $1780.62 \pm 584.34 *$ & $261.12 \pm 68.47^{*}$ & $187.22 \pm 60.61 *$ \\
\hline
\end{tabular}

Values were shown as mean \pm S.D. Statistical significance of the treatment was done by using one-way ANOVA followed by Dunnet's test. Results were expressed as picomoles of resorufin formed $/ \mathrm{min} / \mathrm{mg}$ protein. $* p<0.01, * * * p<0.001$.

that there is a significant inhibition of P450 enzymes by the extract of $P$. amarus in vitro.

Inhibition of P450 Enzymes in Vivo There was a significant induction of the P450 enzymes after phenobarbitone administration. However the rate of induction of the liver P450 enzymes varied. The CYP1A1 (EROD) showed maximum induction (144 fold) while CYP1A2 (MROD) was 40 fold and CYP2B1/2 (PROD) 48 fold of that of untreated (normal) liver. Oral administration of $P$. amarus $(250 \mathrm{mg} / \mathrm{kg}$ b. wt.) was found to reduce the activity of these enzymes almost to the same level. Moreover increasing concentration of P. amarus by three times $(750 \mathrm{mg} / \mathrm{kg} \mathrm{b}$. wt.) did not correspondingly increase the inhibition of these enzymes in vivo significantly (Table 1).

\section{DISCUSSION}

P450 is involved in several biological interactions involving hydroxylation, epoxidation, oxygen and nitrogen dealkylation, oxidative deamination, dehydrogenation etc. ${ }^{13)}$ While some of the biological reactions of P450 are highly essential for the removal of xenobiotics from the body, these reactions are also involved in the activation of xenobiotics to active metabolites, which can be highly injurious to the body. Hence P450 can be considered as double-edged weapon and its control is highly needed in the physiological balance of the body.

P450 enzymes have a significant role in the cancer causation. Most of the carcinogens are metabolized by P450 enzymes to their ultimate carcinogen. ${ }^{14)}$ Results presented in this paper indicate that this metabolism could be significantly inhibited by $P$. amarus extract and it will result in the inactivation of carcinogen and subsequently animals will not develop tumors. This is supported by our earlier observation that $P$. amarus extract significantly reduces the tumor development in different models, which we have employed. ${ }^{4,5,15}$ ) Present results indicated that $P$. amarus inhibits at least four different P450 enzymes at very low concentration and this could be one of the mechanisms of action of $P$. amarus on carcinogenesis. Other enzymes, which are inhibited by $P$. amarus, are topoisomerase and CDC 2 kinase. ${ }^{7)}$

The inhibition of $\mathrm{P} 450$ by $P$. amarus has been successfully used in the traditional medical practice. Many of the xenobiotics are metabolized in the liver where it produces maximum toxicity. $P$. amarus has been found to be hepatoprotective $^{16)}$ as it inhibits the metabolism and so its toxicity. Moreover inhibition of P450 could delay the metabolism of therapeutics and thereby increase their bioavailability. $P$. amarus have been reported to have antiviral activity and this has been reported due to the presence repandusinic acid A and niruriside. ${ }^{17)}$ Mechanism of inhibition of P450 enzymes by $P$. amarus is not known at present. The inhibition of activity in vitro could be due to the direct inactivation of the enzyme and in vivo inhibition could be either due to direct inhibition of the enzyme activity or the inhibition of expression of enzyme activity induced by phenobarbitone.

The active ingredient responsible for the activities of $P$. amarus is not known. A variety of hydrolysable tannins isolated from $P$. amarus were found to be potent inhibitors of protein kinases thus inhibit signal transduction. ${ }^{18)}$ The presence of several lignans such as phyllanthin and hypophyllanthin, polyphenols such as quercetin, astragalin and some el- 
lagitannins such as catechin, epigallocatechin were isolated from $P$. amarus. ${ }^{19)}$ The concentration of the extract needed for $50 \%$ inhibition is approximately $5 \mu \mathrm{g} / \mathrm{ml}$ indicating that the concentration of the active ingredient needed for inhibition of P450 enzymes could be very low, which may act as a suicide substrate for P45. However this needs further experimentation. Inhibition of P450 enzymes, topoisomerase as well as protein kinases by this extract make it as one of the major agent to be pursued for future cancer research.

Acknowledgements Authors acknowledge Dr. R. Krishnakumar and Dr. S. Sreelatha, Scientists, Rubber Research Institute of India, Kottayam for their kind help during the investigation.

\section{REFERENCES}

1) Okita R. T., Masters B. S., "Text Book of Biochemistry with Clinical Correlation," 5th ed., ed. by Devlin T. M., Wiley-Liss, New York, 2002,pp. 466-484.

2) Conney A. H., Ann. Rev. Pharmacol. Toxicol., 43, 1-30 (2003).

3) Caballero F., Gerez E., Batlle A., Varquez, E., Br. J. Cancer, 86, 630635 (2002).

4) Rajeshkumar N. V., Kuttan R., J. Ethnopharmacol., 73, 215-219
(2000).

5) Rajeshkumar N. V., Joy K. L., Kuttan G., Ramsewak R. S., Nair M. G., Kuttan R., J. Ethnopharmacol., 81, 17-22 (2002).

6) Raphael R., Sabu M. C., Hari Kumar K. B., Kuttan R., Amala Res. Bull., 23, 183-194 (2003).

7) Raphael R., Ajith T. A., Joseph S., Kuttan R., Teratogen Carcinogen Mutagen, 22, 285-291 (2002).

8) Hari Kumar K. B., Kuttan R., Phytomedicine, 12, 494-500 (2005).

9) Pohl R. J., Fouts J. R., Anal. Biochem., 107, 150-155 (1980).

10) Nerurkar P. V., Park S. S., Thomas P. E., Lubet R. A., Proc. Am. Assoc. Cancer Res., 34, A931 (1993).

11) Mazel P., "Fundamentals of Drug Metabolism and Drug Disposition," ed. by La Duq B. N., Mandel H. G., Way E. L., Williams \& Wilkins, Baltimore, 1971, pp. 546-578.

12) Lowry O. H., Rosebrough N. J., Farr A. L., Randall R. J., J. Biol. Chem., 193, 265-275 (1951).

13) Aguiar M., Masse R., Gibbs B. F., Drug Metab. Rev., 37, 379-404 (2005).

14) Guengerich F. P., Shimada T., Chem. Res. Toxicol., 4, 391-407 (1991).

15) Joy K. L., Kuttan R., J. Clin. Biochem. Nutr., 24, 133-139 (1998).

16) Sane R. T., Kuber V. V., Menon S., Curr. Sci., 20, 1243-1246 (1995).

17) Calixto J. B., Santos A. R., Filho V. C., Yunes R. A., Med. Res. Rev., 18, 225-258 (1998).

18) Polya G. M., Wang B. H., Foo L. Y., Phytochemistry, 38, 307-314 (1995).

19) Foo L. Y., Phytochemistry, 39, 217-224 (1995). 